\title{
Fixed implant supported restorations versus classical acrylic full dentures in elderly patients: Assessing the satisfaction degree
}

Gabriel CIOCHINDA ${ }^{1}, \mathrm{MD}$, PhD student, Prof. Augustin MIHAI ${ }^{1}, \mathrm{MD}, \mathrm{PhD}$, Univ. Assist. Viorel Stefan PERIEANU ${ }^{1}, \mathrm{MD}, \mathrm{PhD}$, Assoc. Prof. Mihai BURLIBASA ${ }^{1}, \mathrm{MD}, \mathrm{PhD}$, Univ. Assist. Madalina Violeta PERIEANU ${ }^{1}, \mathrm{MD}, \mathrm{PhD}$, Lecturer Cosmin MEDAR ${ }^{1}, \mathrm{MD}, \mathrm{PhD}$, Lecturer Traian BODNAR ${ }^{1}$, MD, PhD, Univ Assist. Radu COSTEA ${ }^{1}, \mathrm{MD}$, PhD student, Lecturer Madalina MALITA ${ }^{1}$, MD, PhD, Raluca COSTEA ${ }^{2}$, MD, Assoc. Prof. Ileana IONESCU ${ }^{1}$, MD, PhD, Lecturer Corina Marilena CRISTACHE ${ }^{1}, \mathrm{MD}, \mathrm{PhD}$, Univ. Assist. Maria Glencora COSTACHE ${ }^{1}, \mathrm{MD}, \mathrm{PhD}$, Prof. Dana Cristina BODNAR ${ }^{1}, \mathrm{MD}, \mathrm{PhD}$

1"Carol Davila" University of Medicine and Pharmacy, Bucharest

${ }^{2}$ S.C. DENTEXPERT MAGIC COM S.R.L. Brasov

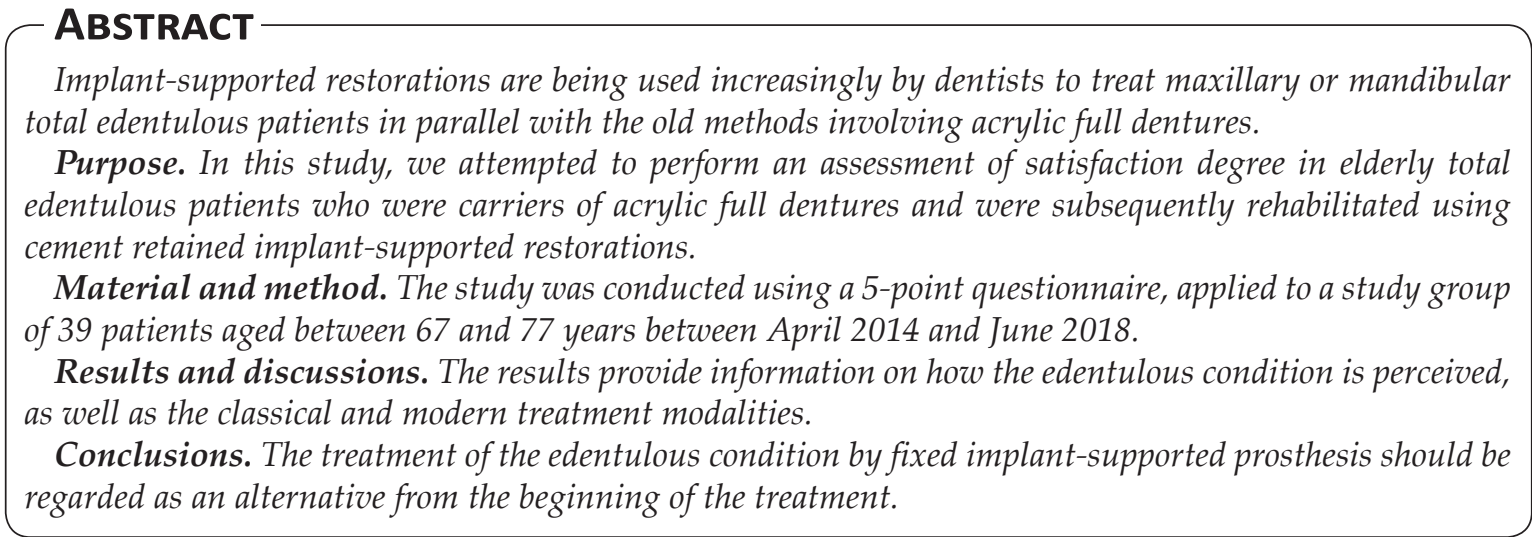

Keywords: acrylic full dentures, implant-supported fixed full-dentures

\section{INTRODUCTION}

As is well known, edentulous condition represents a pathological state with a wide spread among the elderly population in Romania. Not only in elderly patients, but in any class of patients, the edentulous condition has a negative impact on functionality and aesthetics, but also on mental health, being perceived by the patient as a great disability.

Thus, elderly patients are a distinct category with a specific medical condition which also af- fects the oral cavity. The increased degree of difficulty in making prosthetic restorations, due to general deficiencies, determines the need for a treatment protocol to help improve the life quality in this age group (1-5).

\section{GENERAL DATA}

If we refer to the practice of current dentistry, we must keep in mind that the elderly patient should be treated in a special, preferential 
manner because it has a specific general pathology with direct impact on the oral cavity (1-9). Oral dental conditions and quality of life are interdependent, with psychological consequences appearing before the social ones. Diseases and dental treatments have a direct effect on functions and aesthetics. Wearing full-arch dentures interferes with satisfactory nutrition, clear speech, unrestrained laughter, diminishing the overall well-being of elderly patients $(1-5,10-$ 16).

Bone loss in the elderly patients is a common phenomenon which occurs following tooth loose, and which hinders prosthodontic treatment. Analysis of remaining edentulous ridges is an extremely important element, part of the edentulous patient's assessment, along with other significant medical factors such as (1-5): physical disabilities, neuromuscular disorders, respiratory disorders, skin and mucosal disorders, influence local oral conditions. The lack of prosthetic restorations, regardless of their type, prevents proper and balanced nutrition, with direct impact on the health of the whole organism (1-5, 10-16).

But in the last three decades, the use of dental implants has made possible to efficiently treat edentulous patients and replace the classic acrylic full dentures with fixed implant-supported restorations, mobilizable structures or overdentures, depending on the clinical situation, technical and material conditions, cost and last but not least the patient's wishes (1-5). To achieve this type of treatment, complex imaging exams are also needed. But in this paper we will mainly refer to the advantages of cement retained implant supported full bridges, compared to classical removable prosthetic restorations (with reference to acrylic full dentures) in elderly patients.

\section{PURPOSE}

But before proceeding to the actual description of the study, we would like to briefly describe a few aspects, which we will insist on in this paper (1-5):

Acrylic full denture is still the most widespread treatment option for patients in Romania. Thus, this type of prosthetic restoration remains a good treatment solution where the edentulous prosthetic field allows us to create a prosthesis that ensures maintenance, support and stability on the prosthetic field, without neglecting the principles of masticatory efficiency, physiognomy and phonation, which allow a complete rehabilitation of the dento-maxillary system.

The main advantages of acrylic full denture can be described as follows $(1-5,10-16)$ : it is the cheapest of treatment solutions; the facilities and the implementation technique are available to any dental office and dental laboratory; is the least invasive of treatment solutions; is easy and inexpensive to repair or modify; the time required for restoration is shorter compared to other treatment solutions; it can easily be cleaned and disinfected.

Among the disadvantages of the acrylic full denture, we recall (1-5): the success of prosthesis is largely conditioned by the prosthetic field; maintenance and stability are more difficult to achieve; the psychological comfort of the patient is lower compared to other treatment solutions; the extension of the prosthesis affects the patient's sense of taste; the materials from which they are made may have an irritant effect on the mucosa; the accommodation period is more difficult and there is a risk of lesions or ulcerations of the mucosa; bone resorption recorded are higher than for other treatment solutions; due to the volume and coverage of palatal rugae, the phonation may be affected; chewing efficiency is lower compared to other treatment solutions.

Cement retained implant supported full bridges acquire the meaning of "fixed" when the aggregation of the superstructure to the infrastructure is achieved in the cementation or soldering process and can be achieved only in the cases when the prosthetic abutments are parallel (1-5).

Among the advantages of the use of cement retained implant supported full bridges, we will present very concisely, those we considered to be the most important (1-5): favors axial loading of dental implants; is easily corrected for an active superstructure; the price of a fixed superstructure is lower compared to the removable overdentures; the technology is accessible to most dental laboratories; the times and stages of creating are shorter than a removable denture; access is easy in the posterior area in the case of small oral cavities; the psychological comfort of the patient is very good; atrophy of the prosthetic field are much lower compared to full dentures; does not affect the taste of the patient.

There are also a number of disadvantages of these cement retained implant supported full 
bridges, of which we mention (1-9): cannot be removed periodically or at certain times to check it or to have access to dental implants; using strong cements, there is a risk that their removal will no longer be possible, and the weaker cement fixing capacity is not always guaranteed; hygiene is deficient especially in the distal zone of the bridge, which can lead to gingival retraction or the loss of dental implants; physiognomy is more difficult to achieve, especially if bone resorption are present in the oral cavity; sometimes, over time, partial loosening of the restoration may occur, which may sometimes lead to ablation; there is a risk of cement particle retention around the dental implants, which can cause irritation and peri-implantatitis by breaking the epithelial insertion and favoring penetration of the bacteria into the periimplantary bone; periodic radiological checks.

Starting from those mentioned in the first part of the material, in this study we attempted to perform a assessment of satisfaction degree in elderly patients, both maxillary and mandibular edentulous patients, who were carriers of classical acrylic full dentures and who, due to the discomfort caused by them, were rehabilitated using cement retained implant supported restorations. In fact, it represents the very purpose of the study.

In a first stage, 365 maxillary and mandibular edentulous patients from several cities in the country (București, Braşov, Piteşti, Alexandria, Constanța, Sibiu, Feteşti, Otopeni etc.) were monitored but, of them, only 39 patients were selected following a very rigorous process for implanto-prosthetic therapy with cement retained implant supported full bridges. The small number of edentulous patients (39 patients, namely $10.68 \%$ of the total monitored patients) who have benefited from this implant supported rehabilitation was primarily due to the fact that they were part of a risk group patients for implant therapy, elderly patients, the failure in their case is extremely high due to a very poor health condition, and secondly due to the costs, which proved to be much higher than most of the income of these patients, all of them being retired persons.

Specifically, in order to accomplish this study, we opted for the classical method of the questionnaire. In this sense, we designed a questionnaire, with 5 questions, we consider very concise. This questionnaire was applied to the 39 selected patients previously discussed, aged between 67 and 77 maxillary and/or mandibu- lar edentulous, after they were rehabilitated with acrylic full dentures for a certain period of time, due to the discomfort caused by this type of prosthetic devices they opted for cement retained implant supported full bridges. The study was conducted between April 2014 and June 2018 , assessing the patient's satisfaction degree regarding cement retained implant supported full bridges, assessment being made immediately and after 12 months from the insertion of these prosthetic devices in the oral cavity of the patients. The gender distribution of subjects included in the study was as follows: 22 patients (representing 56.41\%) were female and $17 \mathrm{pa-}$ tients (representing 43.59\%) were male (Fig. 1).

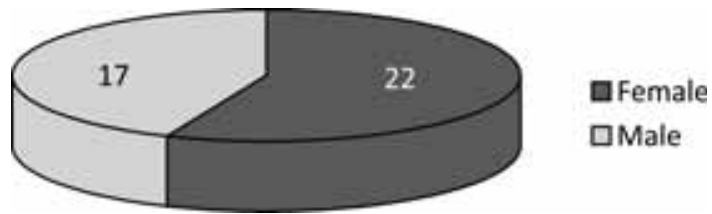

FIGURE 1. Gender distribution of patients involved in the study.

Next, we will present the questionnaire applied to the 39 subjects:

1. How did you perceive in the first phase the edentulous condition: $a$. As a great infirmity that can not be overcome; $b$. As a major physiognomy, phonetic and masticatory discomfort, but which could be rehabilitated by an acrylic full denture; c. As a minor shortcoming, due to elderly that can easily be overcome?

2. Cement retained implant supported restorations treatment option has been presented to you by the dentist: $a$. From the beginning of the treatment, as an alternative to the acrylic full dentures; $b$. After a period of time, when you could not accommodate the classical acrylic full denture; c. The implant supported treatment alternative has not been presented to you by the dental practitioner, but you have learned this therapeutic solution in other ways (from other dental practitioners, from friends, from the Internet etc.)?

3. When did you find that a treatment alternative for edentulous condition is cement retained implant supported full bridges, how did you treat this opportunity? a. With great confidence; b. Skeptics, but as a possible therapeutic alternative; c. With total mistrust, with pessimism, but still with no other convenient quality/ price option.

4. How did you assess the therapeutic alternative by inserting dental implants followed by creating a cement retained implant supported 
full bridges compared to the acrylic full dentures? a. As a saving solution, very expensive but extremely functional; $b$. As another insufficiently experienced treatment option, but as a possible alternative to the acrylic full denture; $c$. As a simple treatment solution, more expensive than the classic variants, but very efficient fom functionally point of view.

5. At twelve months after the insertion of cement retained implant supported full bridges, how did you appreciate this treatment alternative: $a$. Very convenient but also very functional and maintenance-friendly; $b$. Fair in terms of convenience and functionality, but also with a lot of extra maintenance costs; c. A poorly chosen therapeutic solution, very deficient and extremely inconvenient in terms of quality/price ratio?

\section{RESULTS AND DISCUSSIONS}

Following the evaluation of the answers for the 5 questions, the following issues emerged:

In the first question related to the primary perception of the edentulous condition, 18 subjects (representing $46.15 \%$ ) perceived this condition as a great infirmity that cannot be overcome (answer a), while 21 of the subjects (representing 53.85\%) considered it a discomfort that could be rehabilitated by an acrylic full dentures (Fig. 2).

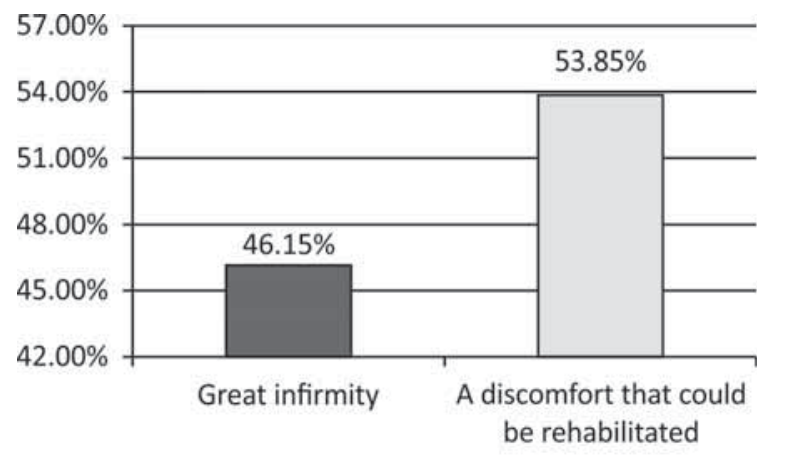

Great infirmity

A discomfort that could be rehabilitated

FIGURE 2. Initial perception of edentulous condition

Regarding the method of presentation of fixed implant-supported restorations for 10 subjects (representing 25.64\%), this treatment variant was initially presented at the start of edentulous condition treatment, for 16 subjects (representing $41.03 \%$ ) the presentation of this alternative treatment was performed after a period of use of classical acrylic full dentures, while for 13 patients (representing 33.33\%) the treating physician never presented this treatment option (Fig. 3).

Concerning patients' attitude towards fixed implant-supported rehabilitation of edentulous condition, 28 of the subjects $(71.79 \%)$ have treated this treatment option with confidence (answer a), 7 subjects (representing 17.95\%) were skeptical they considered it a possible alternative of treatment, while 4 subjects (representing 10.26\%) were totally distrustful (Fig. 4).

Comparatively analyzing implant insertion followed by fixed implant-supported restorations versus treatment with acrylic full dentures, 27 patients (representing 69.23\%) considered it to be a simple and very effective solution (answer c), 10 of the patients involved in the study (representing $25.64 \%$ ) considered it a very expensive but extremely functional solution, while only 2 patients (representing 5.13\%) considered it an alternative treatment insufficiently experienced but a possible alternative to classic options (Fig. 5).

The last point of the questionnaire related to the evaluation at 12 months after the insertion of fixed implant-supported restorations 29 of the patients involved in the study (representing $74.36 \%$ ) considered it very convenient and functionally effective, while 10 patients (representing $25.64 \%$ ) considered this treatment as satisfactory from a functional point of view but with many additional costs in terms of its long-term maintenance (Fig. 6).

\section{CONCLUSIONS}

Following the answers evaluation to the 5 questions of the questionnaire, we can conclude on several aspects, some extremely important, as follows:

Less than $50 \%$ of the subjects involved in the study (46.15\%) considered the total edentation to be a major disability, aspect that checks the data from the literature, while the rest of the patients $(53.85 \%)$ appreciated the edentulous condition to be a major physiognomic, phonetic and masticatory discomfort but it could be rehabilitated by an acrylic full dentures.

Regarding the treatment proposal for cement retained implant supported full bridges, only $25.64 \%$ of the patients involved in the study were offered this therapeutic alternative from the start, which indicates a certain safety, but also a very high dose of unconsciousness and a desire to collect some money as quickly as 


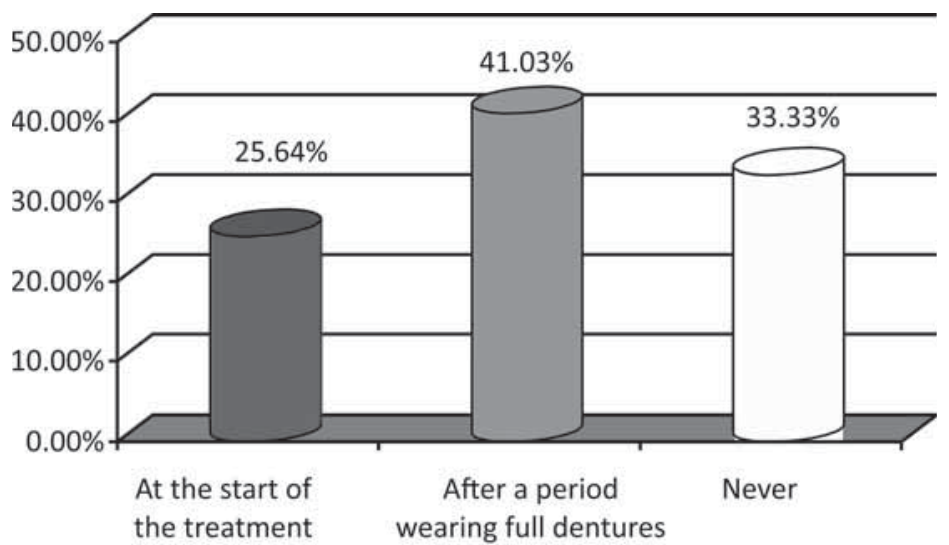

At the start of the treatment

After a period wearing full dentures

$\square$ Never

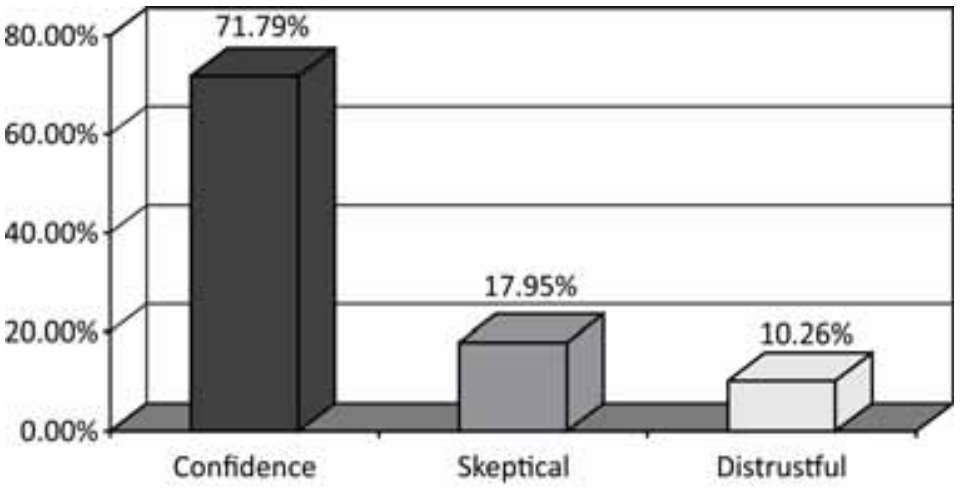

Confidence

$\square$ Skeptical

$\square$ Distrustful

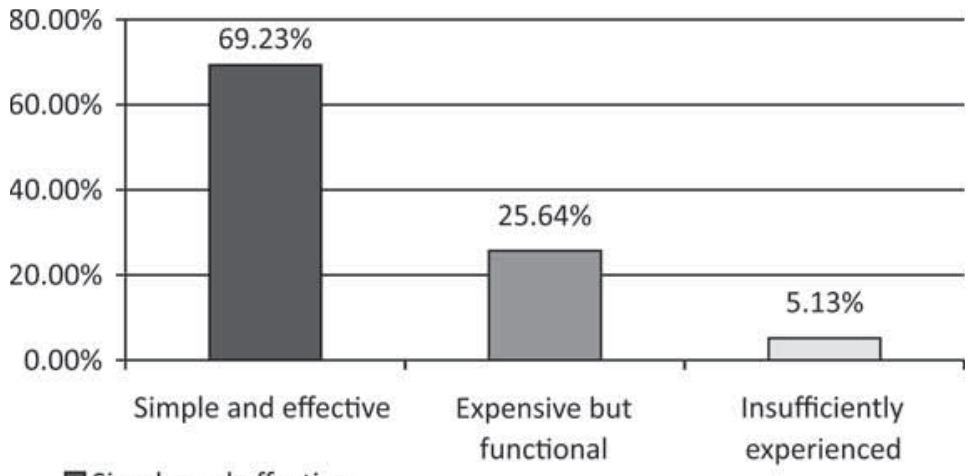

Simple and effective

$\square$ Expensive but functional

$\square$ Insufficiently experienced

possible of the dentists who made the proposal, because they were not taking into account that this category of patients are elderly patients, patients at risk, and the possibility that the failure of this therapeutic solution by insertion of dental implants will be much higher.
FIGURE 3. Presentation of fixed implantsupported restoration treatment method for patients

FIGURE 4. Attitude towards the opportunity to use fixed implantsupported rehabilitation in the treatment of edentulous condition

FIGURE 5. Comparative attitude between the insertion of implants followed by the implant-supported restorations and the acrylic full dentures
The percentage of patients to whom this therapeutic solution for treating edentulous condition by cement retained implant supported full bridges was presented later or who learned about it through other sources of information (other dental practitioners, friends, in- 


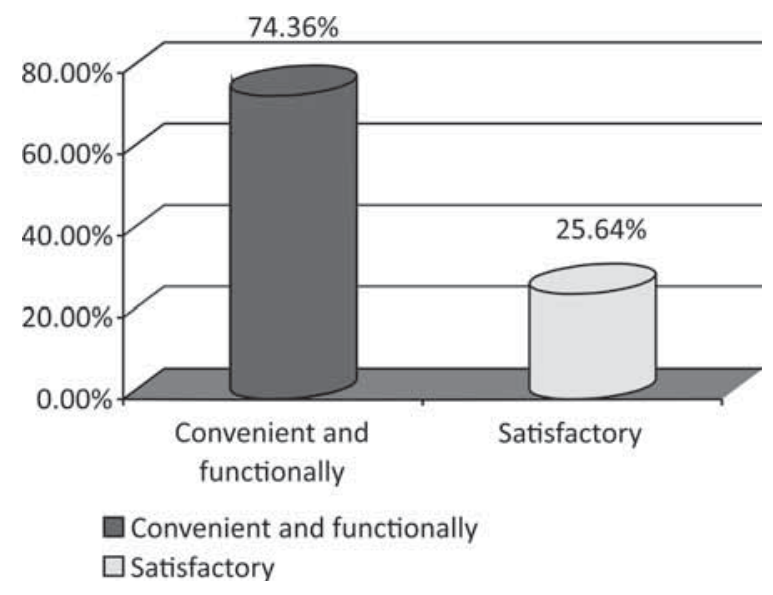

FIGURE 6. Evaluation of implant-supported fixed full restorations 12 months after insertion.

ternet) is very close to the percentage of patients who accepted this treatment with great confidence, on the very good reason that the acrylic full dentures produced them during the time they wore them, massive discomfort in all respects: poor stability, slower mastication, extremely difficult phonation etc.

Most of the subjects involved in the study (approximately 70\%) rated the therapeutic alternative of inserting dental implants followed by creating cement retained implant supported full bridges as an ideal treatment solution, simple, expensive than classic alternatives, but very functional.

At twelve months after the insertion of cement retained implant supported full bridges, all patients rated this therapeutic solution instead of classical acrylic full dentures: $74.36 \%$ of the subjects considered this timplant supported treatment option, as being very convenient, but also very functional and maintenance efficient, while the remaining $25.64 \%$ of patients appreciated this therapeutic alternative as being satisfactory in terms of convenience and functionality, but also with a lot of extra maintenance costs. In one word, all patients expressed their gratitude for this therapeutic solution: for $3 / 4$ of the subjects satisfaction was very high, while for $1 / 4$ of the patients involved in study satisfaction exists, but it is slightly lower, in particular due to the very high total cost of the treatment solution (insertion of dental implants, creating cement retained implant supported full bridge and their subsequent maintenance).

Acknowledgement: In this article, all the authors have equal contributions.

\section{REFERENCES}

1. Malița M, Armean P. Soluții optime de tratament restaurator protetic în scopul îmbunătătirii calității vieții la pacienții vârstnici. În: Progrese în medicina dentară, Vol VIII, pp. 132-204, coordonatori: Cristache C.M., Burlibașa M., Trăistaru V., Malița M., Editura Ars Docendi, București, 2013.

2. Malița M, Burlibașa M, Stănescu C. Protezarea mobilă la pacienții geriatrici cu status general precar, o provocare pentru practician (partea I). În: Progrese în medicina dentară, Vol. XI, pp. 16-48, coordonatori: Temelcea A., Grigorescu I., Costea R., Eftene O., Editura Ars Docendi, București, 2015.

3. Vanini M, Cristache CM, Pantea M, Butnărașu C, Cristache G, Burlibașa M. Edentația totală maxilară. Particularități moderne de protezare. În: Probleme în medicină și biologie, Vol. V, pp. 166-240, coordonatori: Marcov E.C., Oancea L., Popovici I.A., David M. , Editura Ars Docendi, București, 2014.

4. Borțun C, Bratu D. Protezarea edentației totale. Editura Marineasa, Timișoara, 1998.
5. Bratu D, Fetzer W, Bratu E, Românu M. Puntea pe implante. Editura Helicon, Timișoara, 1996.

6. Cristache CM, Burlibașa M, Cristache G, Drafta S, Popovici IA, Iliescu AA, Zisi S, Burlibașa L. Zirconia and its biomedical applications. Metalurgia International. 16(7), 18, 2011, pp. 18-23.

7. Lazăr V, Chifiriuc C, Bucur M, Burlibașa M, Sfeatcu R, Stanciu G, Savu B, Trăistaru T, Cernat R, Suciu I. Investigation of dental-plaque formers biofilms by optic and confocal laser scanning microscopy and microbiological tools. Revista MedicoChirurgicala a Societatii de Medici si Naturalisti din lasi, Vol. 112, No. 3, 2008, pp. 812-820.

8. Burlibașa M, Cuculescu M., Tănase G., Mihai A., Temelcea A. Popa E. Dental alloys of prothetic use - A retrospective of their use in Romania. Metalurgia International. Vol. XIV, Spec. Issue No. 16, 2009, pp. 51-53.

9. Burlibașa M, Burlibașa L, Gavrilă LB, Gavrilă VR, Gavrilă L. microRNA a macro revolution in medical biotechnologies.
Romanian Biotechnological Letters. Vol. 13, No. 6, 2008, pp. 3977-3983.

10. Popescu FD, Popescu SM, Burlibașa M. Platinum group metals as contact allergens in oral rehabilitation. Metalurgia International. Vol. XV, Spec. Issue No. 3, 2010, pp. 12-18.

11. Cristache CM, lonescu C, Cristache G, Ionescu I, Iliescu AA, Burlibașa M. A 5-year prospective randomised clinical trial on the efficiency of two different attachement systems as retention for implant-supported mandibular overdenture. Radiographic assesment, cost analysis and final evaluation of treatment, s success. Metalurgia International. Vol. XIV, Spec. Issue No. 16, 2009, pp. 27-34.

12. Cristache $C M$, lonescu $C$, Burlibașa $M$, Cristache G, Iliescu AA, Dumitriu HT. Rettentive anchors versus magnets as attachment systems for mandibular overdenture. A 5 year prospective randomised clinical study. Metalurgia International. Vol. XIV, Spec. Issue No. 16,2009, pp. 59-64. 
13. Mocuța D, Popovici LR, Dumitriu AS, Burlibașa L, Ionescu CA, Sfeatcu R. Life quality-condition of social welfare. Metalurgia International 14, 2009, 62-64.

14. Ștețiu AA, Oleksik M, Oleksik V, Ștețiu M, Burlibașa M. Mechanical behavior of composite materials for dental obturations.
Romanian Biotechnological Letters 18(4), 2013, 8528-8538.

15. Bodnar DC, Pantea M, Bodnar T, Burlibașa M, Dumitru SG, Cristache CM. Patologia mucoasei orale la pacienții vârstnici studiu clinico-statistic. Acta Medica Transilvanica 2(2), 2012, 56-60.
16. Bodnar DC, Dimova C, Bodnar T, Cristache CM, Burlibașa M, Sfeatcu R. Dental management of patient with psychiatric disorders. Modern Medicine 17(10), 2010, 538-543. 